Discussion Paper No. 14-090

How Do Employment Tax Credits Work?

- An Analysis of the

German Inheritance Tax

Benedikt Franke, Dirk Simons, and Dennis Voeller

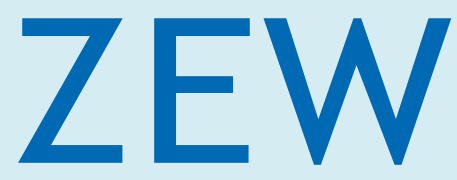

Zentrum für Europäische Wirtschaftsforschung $\mathrm{GmbH}$

Centre for European

Economic Research 
Discussion Paper No. 14-090

\section{How Do Employment Tax Credits Work? - An Analysis of the German Inheritance Tax}

Benedikt Franke, Dirk Simons, and Dennis Voeller

Download this ZEW Discussion Paper from our ftp server:

http://ftp.zew.de/pub/zew-docs/dp/dp14090.pdf

Die Discussion Papers dienen einer möglichst schnellen Verbreitung von neueren Forschungsarbeiten des ZEW. Die Beiträge liegen in alleiniger Verantwortung der Autoren und stellen nicht notwendigerweise die Meinung des ZEW dar.

Discussion Papers are intended to make results of ZEW research promptly available to other economists in order to encourage discussion and suggestions for revisions. The authors are solely responsible for the contents which do not necessarily represent the opinion of the ZEW. 


\title{
How do employment tax credits work? - An analysis of the German inheritance tax -*
}

\author{
Benedikt Franke \\ University of Mannheim
}

Dirk Simons

University of Mannheim

\author{
Dennis Voeller ${ }^{\dagger}$
}

University of Mannheim

\section{Working Paper - November, 2014}

\begin{abstract}
Employment tax credit programs have been repeatedly used during economic crises, although their usefulness is empirically contestable. The objective of this paper is to quantify the tax effects of employment tax credit programs. A recent revision of the German inheritance tax law provides an eminent opportunity to analyze the effects caused by such a preferential treatment. The tax liability depends on a company's future employment expenses. Hence, we use micro-level data of realized business transfers from the German Inheritance Tax Statistic and combine them with a simulation of the future development of employment over the relevant time-horizon. We identify the magnitude of tax reductions granted to business transfers under a preferential treatment. Further, we demonstrate that these reductions are considerably larger in times of economic growth. Our findings also suggest that employment tax credits have pro-cyclical effects and specifically foster transfers between unrelated parties. Finally, the preferential treatment of business transfers does not provide incentives to increase employment.
\end{abstract}

JEL-Classification: C15, H30, K34

Keywords: Alternative tax treatments, Employment tax credits, Inheritance tax, Simulation

${ }^{*}$ We thank the Research Data Centre of the German Federal Statistical Office and the Statistical Offices of the Länder for providing us with micro-level inheritance tax data. We are also grateful to participants of the 2nd EIASM Workshop on Current Research in Taxation in Muenster, the 2013 EAA Annual Meeting in Paris, and colleagues in the MannheimTaxation (MaTax) ScienceCampus for their valuable comments on previous drafts of this paper. Dennis Voeller gratefully acknowledges financial support by the Fritz Thyssen Foundation and the Julius Paul Stiegler Memorial Foundation.

${ }^{\dagger}$ Corresponding author: Chair of Business Administration and Accounting, University of Mannheim, 68131 Mannheim, Germany, e-mail: voeller@bwl.uni-mannheim.de, phone: +(49) 621-181 1638, fax: $+(49)$ 621-181 1665 . 


\section{Introduction}

Employment tax credits tied to the creation or preservation of jobs have been regarded an instrument to alleviate the consequences of economic crises. For example, the United States enacted federal programs such as the Work Opportunity Tax Credit, which was introduced in 1996 and reauthorized and amended multiple times, or the HIRE Act of 2010. Further, employment tax credit programs have been enacted in the proceedings of the financial crisis, e.g., in Japan in 2011 (Ministry of Finance Japan, 2010) or in France in 2013 (Competitiveness and Employment Tax Credit - CICE).$^{1}$ The intention of these programs has been to stimulate the employment of specific groups of workers or employment in general (Neumark, 2011; Heaton, 2012). However, empirical evidence on the efficacy of employment tax credit programs with respect to labor demand is mixed. ${ }^{2}$ Besides the uncertain effects on the labor market, the exclusive applicability of employment tax credits to business property has initiated controversial debates: proponents argue that a lower tax burden on business property helps to create or secure jobs and thereby serves the public welfare. Opponents criticize the legitimacy of the asymmetric treatment of private and business transfers. In a current decision, the German Federal Supreme Tax Court doubts that the effective treatment of business property under the German inheritance tax law is consistent with the German Constitution (BFH, 2012). A final decision on this issue is to be expected from the German Federal Constitutional Court in fall $2014 .^{3}$ Another prominent example for this type of discussion is the US administration's plan for a business tax reform that envisions the elimination of seemingly unjustified subsidies and a broader tax base as a precondition for a more effective tax system (The White House (ed.), 2012).

The objective of our paper is to quantify the tax effects of employment tax credit programs. ${ }^{4}$ For this purpose, we exploit a recent reform of the German inheritance tax law, where two alternative types of employment tax credits have been introduced. Relying on the proponents' argument, the German government explicitly refers to the preservation of jobs as a justification, see (Deutscher Bundestag, 2008, p. 1). However, estimates of the German government encourage the opponents' doubt concerning the legitimacy of positive discrimination of business property. The inheritance tax revenue is expected to drop from 4.7 billion EUR to 2.7 billion, i.e., by $44 \%$, due to the introduction of employment tax credits. Therefore, evidence on the tax effects of employment tax credits is useful not

1 Additionally, employment tax credit programs focused on certain groups of employees are implemented all over the world, e.g., the Apprenticeship Job Creation Tax Credit (AJCTC) in Canada or tax credits in conjunction with the Skills Development Act in South Africa.

2 See, for example, the controversial discussion of the New Jobs Tax Credit (NJTC) program, a similar tax credit that was designed as a political response to the recession in the mid-1970s, by Perloff and Walter (1979), and Bartik and Bishop (2009). For a current overview of tax structures and tax credits in the G7 countries see e.g., Profeta et al. (2014) pp. 734-739.

3 For a description of the ongoing legal proceeding see BVerfG, 2012.

4 This study focuses on tax credits that grant a tax relief to employers, but not to employees. 
only from a legislator's perspective but also from an economic point of view.

The German setting is particularly useful for our analysis as it offers two employment tax credit alternatives that differ with regard to their employment requirements and the tax reduction they provide. Our analysis is based on proprietary micro-level data from the German Inheritance Tax Statistic of 2011. Specifically, we use information on the value of the transferred property and on the applicable tax bracket of all German business transfers. ${ }^{5}$ The final inheritance tax under both alternatives depends on future employment expenses. Due to the multi-period design of the new tax law enacted in 2008, resulting tax payments are not finally determined before 2016. Hence, we simulate employment expense paths for all individual business transfers to quantify the effects of employment tax credits on tax payments.

Our results contribute to the literature in three ways: First, the study provides evidence on effective inheritance tax rates levied on business transfers in Germany. Thereby, it adds to the long-lasting political and judicial controversy about the preferential treatment of business property (Houben and Maiterth, 2011). Under the employment tax credit program, more than $95 \%$ of the considered business transfers remain effectively untaxed. In contrast, if only tax exemptions available to private transfers could be used, this would only hold for $64 \%$ of the transfers. The average effective tax rate can be lowered from $4.14 \%$ to only $0.05 \%$. The results also indicate that tax benefits are significantly larger for the transfer of large properties. For example, the average effective tax rate on large transfers is between $0.53 \%$ and $1.61 \%$ under the preferential treatment for business transfers, compared to an average tax rate of $21.41 \%$ that would be levied on private transfers. Transfers that fall into a low tax bracket due to a close legator-successor relationship tend to benefit less from the preferred tax treatment. As these transfers are subject to a lower tax rate and enjoy higher tax exemptions even in the absence of any preferential treatment for business transfers, their additional tax reductions are smaller. Thus, an abolishment of preferential provisions for business transfers would lead to a more progressive tax system and is likely to affect intergenerational succession planning.

Second, the study provides detailed results with regard to the size of the transferred property and to the relation between legator and successor, which adds to the continuing debate about tax progressivity and tax effects on succession planning (Pickety and Saez, 2007; Kopczuk, 2013). Therefore, we focus on those transfers that would lead to a tax payment under private taxation. ${ }^{6}$ They are more likely to benefit from a preferential treatment. As expected, taxpayers' benefits from employment tax credits are even bigger

5 To ensure privacy of the tax filings that is protected by German law, the data is not publicly available. Therefore, our analyses are conducted in cooperation with the Research Data Centre of the German Federal Statistical Office and the Statistical Offices of the Länder.

6 As mentioned before, about $64 \%$ of the transfers would not have to pay inheritance tax even in the absence of any preferential provisions for business transfers, due to tax exemptions on the personal level, etc. 
for this subsample. On average, the effective tax rate can be lowered to $0.15 \%$, compared to an average effective tax rate of $11.54 \%$ in the absence of any preferential treatment. The average tax wedge between small and large transfers can be reduced from $11.65 \%$ to $0.43 \%$ under a preferential treatment.

Third, our findings suggest that the benefits of employment tax credits are lower under a recession scenario, which suggests pro-cyclical effects of the employment tax credit program. Thus, our results do not support the popular notion of employment tax credit programs as a counter-cyclical instrument. Our analyses neither suggest that employment tax credits provide incentives to increase employment merely to realize additional tax reductions.

The remainder of this paper is organized as follows. Section 2 describes the institutional setting. Section 3 presents the research design and descriptive statistics. The results are reported and discussed in Section 4. In Section 5, we present multivariate analyses to validate the robustness of our findings and address endogeneity concerns. Section 6 summarizes the key findings of the study and concludes.

\section{Institutional setting}

Since the reform of 2008, the German inheritance tax law offers two employment tax credit alternatives for business successions. ${ }^{7}$ The reform was justified with the prevention of liquidity constraints that might jeopardize the continuation of transferred businesses. Moreover, it should provide incentives to maintain employment levels after a business transfer. The German inheritance and gift tax is levied on the net property received by the successor. Both alternatives, denoted as "standard plan" and "option plan", grant tax credits for successors who maintain a prescribed level of employment expenses over a certain period of time after transferring the business. However, the alternatives differ with respect to their specific expense thresholds, time horizons, and applicable tax exemptions.

The standard plan requires a $15 \%$ definitive taxation of the transferred estate $X$ after a deduction of all available tax exemptions, $T E_{S P}$, at $t=0$. Tax exemptions depend on the relation between the legator and the successor. As in many European countries, transfers between close relatives enjoy fiscal advantages (for an overview see Næss-Schmidt et al., 2011; Eurostat - European Commission, 2012). That is, additional tax exemptions can be used compared to third-party transfers. ${ }^{8}$ Under the standard plan, additional exemptions

\footnotetext{
${ }^{7}$ In the following, we use the term inheritance tax for the German inheritance and gift tax. With some minor exceptions, e.g., a special tax exemption for children after the death of their parents, transfers after death and transfers by gift are treated equally under German law. In the US, the term estate tax is more frequently used. For a detailed description of the US estate tax system see, for example, Batchelder (2009).

8 For example, a tax exemption of 500,000 EUR can be used by spouses under German inheritance tax law. Children are entitled to a tax exemption of 400,000 EUR. Grandchildren and parents (in case of death) can use tax exemptions of 200,000 EUR or 100,000 EUR, respectively, while more distant
} 
apply if the employment expenses, $W_{S P}$, aggregated over five years following the business transfer exceed four times the initial employment expenses, $4 \cdot w_{0}$. Thereby, the average employment expenses, $w_{0}$, paid in the five years preceding the business transfer serve as a basis for the computation. If the requirement is met, $85 \%$ of the transferred net estate remain untaxed. If employment expenses fall short of the threshold, the tax exemption is linearly reduced. If tax exemptions are not completely exhausted in $t=0$, remaining exemptions can be used in period $t=5$. Therefore, the tax base for the standard plan, $T B_{S P}$, can be computed as: ${ }^{9}$

$$
\begin{aligned}
T B_{S P} & =\left(0.15 \cdot X-\min \left\{0.15 \cdot X ; T E_{S P}\right\}\right) \\
& +0.85 \cdot X \cdot \max \left\{0 ; 1-\frac{W_{S P}}{4 \cdot w_{0}}-\max \left\{0 ; \frac{T E_{S P}}{0.85 \cdot X}-\frac{0.15}{0.85}\right\}\right\} .
\end{aligned}
$$

While only $85 \%$ of the transferred estate remain untaxed if the expense threshold is met under the standard plan, meeting the threshold under the option plan guarantees that the business transfer is not taxed at all. Under the option plan, aggregated employment expenses, $W_{O P}$, have to exceed seven times the initial expenses, $7 \cdot w_{0}$, in the seven years after the transfer to completely avoid taxation. The tax exemption is again linearly reduced, if employment expenses are below the threshold. The tax base under the option plan, $T B_{O P}$, is:

$$
T B_{O P}=X \cdot \max \left\{0 ; 1-\frac{W_{O P}}{7 \cdot w_{0}}-\frac{T E_{O P}}{X}\right\} .
$$

Analogous to the provision of tax exemptions, the applicable tax rate, $t_{S P}$ or $t_{O P}$, also depends on the relationship between the legator and the successor. German tax law differentiates between transfers between close relatives such as children or spouses (tax bracket 1), transfers to, for example, siblings, parents, or parents-in-law (tax bracket 2), and transfers without a close family relationship (tax bracket 3). Within each tax bracket, a progressive tax schedule is applied meaning that tax rates rise in the value of the tax base. For example, statutory tax rates range from 7 to $30 \%$ in tax bracket 1 or from 30 to $50 \%$ in tax bracket 3 , depending on the value of the transferred property. Figure 1 illustrates the applicable statutory tax rates based on the respective tax brackets under the German inheritance tax law.

Based on the respective tax bases, $T B_{S P}$ and $T B_{O P}$, and the applicable statutory tax rates, $t_{S P}$ and $t_{O P}$, we are able to determine the expected tax payment of an individual under both alternatives. We denote the expected tax payments as $T_{S P}$ and $T_{O P}$ respectively. The expected tax payments allow for a comparison of tax consequences resulting from the two employment tax credit alternatives. For the standard plan, the present value

relatives and non-related parties are only provided with a tax exemption of 20,000 EUR.

9 For a detailed description of the tax computation see Simons et al. (2012, p. 7). 
Figure 1: Statutory Tax Rates According to German Inheritance Tax Law

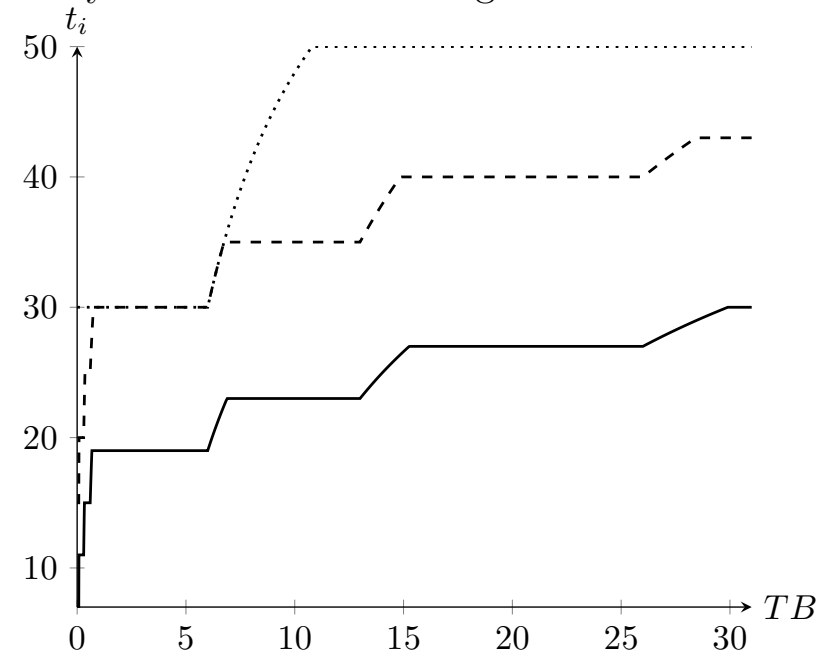

This figure provides statutory tax rate according to German inheritance tax law ( $\$ 19$ I and III ErbStG) depending on the applicable tax base and the respective tax bracket. The statutory tax rate $t_{i}$ with $i \in\{O P, S P, P R I V\}$ is expressed in percent, and the tax base $T B$ is in million euro. The solid line represents statutory tax rates for tax bracket I, the dashed line for tax bracket II, and the dotted line for tax bracket III.

of the expected tax payments is given by:

$$
\begin{aligned}
T_{S P} & =t_{S P} \cdot\left(0,15 \cdot X-\min \left\{0.15 \cdot X ; T E_{S P}\right\}\right) \\
& +t_{S P} \cdot \frac{0.85 \cdot X}{(1+r)^{5}} \cdot \max \left\{0 ; 1-\frac{W_{S P}}{4 \cdot w_{0}}-\max \left\{0 ; \frac{T E_{S P}}{0,85 \cdot X}-\frac{0.15}{0.85}\right\}\right\} .
\end{aligned}
$$

The first summand represents the $15 \%$ share of the taxable estate that is taxed directly after the succession. The second summand represents the subsequent taxation if the expense threshold is not met, i.e., $W_{S P}<4 w_{0}$. The present value of the expected tax payments under the option plan is:

$$
T_{O P}=\frac{t_{O P} \cdot X}{(1+r)^{7}} \cdot \max \left\{0 ; 1-\frac{W_{O P}}{7 \cdot w_{0}}-\frac{T E_{O P}}{X}\right\}
$$

Finally, we compute those tax payments that would occur in the absence of any preferential treatment of business property, i.e., we assume that the transfer of the business is subject to the tax rules for transfers of private property. This serves as a benchmark for the employment tax credit alternatives. The present value of the expected tax payments is denoted as $T_{P R I V}$ and given by:

$$
T_{P R I V}=t_{P R I V} \cdot \max \left\{0 ; X-T E_{P R I V}\right\}
$$




\section{Research design}

\subsection{Inheritance Tax Data}

We make use of proprietary micro-level data from the Inheritance Tax Statistic of 2011 provided to us by the Research Data Centre of the German Federal Statistical Office. The data covers all transfers for which a tax assessment has been done in 2011. The tax statistic provides detailed individual information about the value of transferred property, and about the relation between the legator and the successor. To determine the tax effects of the described employment tax credit alternatives, we obtain the actual values of all transferred business properties $X$ assessed in 2011. ${ }^{10}$ We use this information to determine the applicable tax bracket and tax exemptions that would be granted under current legislation for each business transfer. This procedure is necessary, as many transfers included in the Inheritance Tax Statistic of 2011 are not taxed according to the current legislation. The two employment tax credit alternatives introduced in 2008 are based on a time horizon of up to seven years. Given the typical duration of a tax assessment process, comprehensive evidence on actual tax payments under currently valid law is not yet available. Hence, we use the available transfer data as input for the subsequently described simulation.

Table 1 reports summary statistics for the 14,800 business transfers included in the German Inheritance Tax Statistic of 2011. The variable $X$ is the value of the transferred business property in thousand euro. $T E_{16}, T E_{17}$, and $T E_{13 a}$ are simulated tax exemptions that would have been granted under current legislation based on the value of the business property and the applicable tax bracket of a specific transfer recorded in the data. ${ }^{11} T E_{16}$ depends on the relation between legator and successor, which also defines the applicable tax bracket for a business transfer. It ranges from 20,000 euro for transfers between unrelated parties up to 500,000 euro granted for transfers between spouses. $T E_{17}$ is a tax exemption that is specifically granted to spouses and underage children. However, it does not apply for inter vivos transfers. Therefore, we use information about the cause of each transfer and about the successor provided by the inheritance tax statistic to determine the appropriate amount. As one might expect, the descriptive statistics suggest that this tax exemption has a minor impact on the tax burden as only a relatively small number of successors receive this exemption. The average amount is 29,260 euro. Finally, $T E_{13 a}$ is an exemption tied to the use of the standard plan. The exemption is 150,000 euro for a value of transferred property below 1 million euro and linearly reduces toward zero for values between 1 million and 3 million euro. As the standard and the option plan result in tax payments at different points in time, differences in the present value of tax payments under both methods might occur. We assume in our calculations that the interest rate $r$

\footnotetext{
$\overline{10}$ For practical problems in determining the value of transferred business see e.g., Müller and Sureth (2011). Note that we exclude all transfers not considered to be business successions.

11 The indices represent the corresponding paragraphs of the German inheritance tax code.
} 
Table 1: Summary Statistics - Inheritance Tax Statistic

\begin{tabular}{|c|c|c|c|c|c|c|c|}
\hline \multicolumn{8}{|c|}{ Panel A: Full Sample } \\
\hline & Var. & Mean & $\mathrm{SD}$ & $\mathrm{P} 25$ & $\mathrm{P} 50$ & P75 & $\mathrm{N}$ \\
\hline & $X$ & $1,394.77$ & $25,343.77$ & 26.18 & 150.00 & 459.83 & 14,800 \\
\hline & $T E_{16}$ & 317.13 & 171.40 & 200.00 & 400.00 & 400.00 & 14,800 \\
\hline & $T E_{17}$ & 29.26 & 80.83 & 0.00 & 0.00 & 0.00 & 14,800 \\
\hline & $T E_{13 a}$ & 138.89 & 35.48 & 150.00 & 150.00 & 150.00 & 14,800 \\
\hline \multicolumn{8}{|c|}{ Panel B: By Tax Bracket } \\
\hline & Var. & Mean & $\mathrm{SD}$ & $\mathrm{P} 25$ & $\mathrm{P} 50$ & P75 & $\mathrm{N}$ \\
\hline \multirow{4}{*}{ Tax Bracket 1} & $X$ & $1,173.98$ & $6,056.57$ & 58.09 & 216.59 & 561.39 & 11,624 \\
\hline & $T E_{16}$ & 398.32 & 81.78 & 400.00 & 400.00 & 400.00 & 11,624 \\
\hline & $T E_{17}$ & 37.26 & 89.56 & 0.00 & 0.00 & 0.00 & 11,624 \\
\hline & $T E_{13 a}$ & 136.85 & 38.19 & 150.00 & 150.00 & 150.00 & 11,624 \\
\hline \multirow{4}{*}{ Tax Bracket 2} & $\bar{X}$ & $3,593.14$ & $70,075.72$ & 5.79 & 23.54 & 99.55 & 1,846 \\
\hline & $T E_{16}$ & 19.99 & 0.42 & 20.00 & 20.00 & 20.00 & 1,846 \\
\hline & $T E_{17}$ & 0.00 & 0.00 & 0.00 & 0.00 & 0.00 & 1,846 \\
\hline & $T E_{13 a}$ & 145.74 & 22.83 & 150.00 & 150.00 & 150.00 & 1,846 \\
\hline \multirow{4}{*}{ Tax Bracket 3} & $X$ & 273.16 & $2,439.53$ & 3.72 & 11.42 & 52.41 & 1,330 \\
\hline & $T E_{16}$ & 19.99 & 0.49 & 20.00 & 20.00 & 20.00 & 1,330 \\
\hline & $T E_{17}$ & 0.00 & 0.00 & 0.00 & 0.00 & 0.00 & 1,330 \\
\hline & $T E_{13 a}$ & 147.17 & 19.28 & 150.00 & 150.00 & 150.00 & 1,330 \\
\hline \multicolumn{8}{|c|}{ Panel C: By Value of Transferred Property } \\
\hline & Var. & Mean & $\mathrm{SD}$ & $\mathrm{P} 25$ & $\mathrm{P} 50$ & P75 & $\mathrm{N}$ \\
\hline \multirow{4}{*}{ Small } & $X$ & 129.09 & 135.66 & 15.21 & 76.33 & 214.27 & 11,354 \\
\hline & $T E_{16}$ & 297.87 & 181.08 & 20.00 & 400.00 & 400.00 & 11,354 \\
\hline & $T E_{17}$ & 28.52 & 79.94 & 0.00 & 0.00 & 0.00 & 11,354 \\
\hline & $T E_{13 a}$ & 150.00 & 0.00 & 150.00 & 150.00 & 150.00 & 11,354 \\
\hline \multirow{4}{*}{ Medium } & $X$ & $1,060.45$ & 533.41 & 633.33 & 868.81 & $1,381.91$ & 2,658 \\
\hline & $T E_{16}$ & 384.65 & 109.62 & 400.00 & 400.00 & 400.00 & 2,658 \\
\hline & $T E_{17}$ & 33.79 & 85.93 & 0.00 & 0.00 & 0.00 & 2,658 \\
\hline & $T E_{13 a}$ & 131.82 & 30.14 & 121.36 & 150.00 & 150.00 & 2,658 \\
\hline \multirow{4}{*}{ Large } & $X$ & $20,759.10$ & $108,000.00$ & $3,544.85$ & $5,595.43$ & $12,680.43$ & 788 \\
\hline & $T E_{16}$ & 366.87 & 124.88 & 400.00 & 400.00 & 400.00 & 788 \\
\hline & $T E_{17}$ & 24.76 & 75.13 & 0.00 & 0.00 & 0.00 & 788 \\
\hline & $T E_{13 a}$ & 2.58 & 7.50 & 0.00 & 0.00 & 0.00 & 788 \\
\hline
\end{tabular}

This table provides a description of the inheritance tax data considered in the empirical analysis. Panel A reports summary statistics for the full sample of 14,800 business transfers included in the German Inheritance Tax Statistic of 2011. Panels B and C show summary statistics for subsamples divided by the tax bracket and the size of transferred property, respectively. $X$ represents the value of transferred business properties as reported in the statistic. $T E_{16}, T E_{17}, T E_{13 a}$ are summary statistics of simulated tax exemptions that would be granted under current legislation, given the property value, the chosen tax credit alternative, and the tax bracket of a specific transfer. All values are reported in thousand euro.

is equal to zero.

Panel A shows descriptives based on the full sample. It seems that many tax exemptions exceed the value of the transferred property. Hence, no taxation would occur irrespective of the level of employment expenses. For example, the 75 th percent quantile 
of the transferred properties is smaller than the accumulated amount of tax exemptions at the same quantile. While an individual transfer is not necessarily attributable to the same quantile in all variables, the probability that total tax exemptions exceed the value of the transferred property is high. Hence, we separate the sample by tax brackets and value of transferred property. Panel B shows summary statistics for each of the three tax brackets. Both property values and tax exemptions vary by the tax bracket of the successor. Property values that are transferred to successors that have a more distant or no family relationship with the legator (tax bracket 3) are considerably smaller than property values transferred in tax bracket 1 or 2 . Besides the apparent tax incentives - tax bracket 1 provides lower tax rates and additional tax exemptions compared to tax bracket 3 - there obviously exist numerous non-tax reasons for this finding, especially given the important role of family businesses in Germany (e.g., Miller et al., 2003). In Panel C we differentiate by the value of transferred property. Small transfers are defined as transfers with a property value up to 500,000 euro, medium transfers have a property value between 0.5 and 2.5 million euro, and large transfers exhibit a property value of more than 2.5 million euro. ${ }^{12}$ The descriptive statistics show that $76 \%$ of all business successions are transfers below 500,000 euro. However, they also suggest that for the remaining $24 \%$ of the cases, property values exceed the available tax exemptions considerably. Thus, significant tax payments could be expected in the absence of employment tax credits.

\subsection{Simulation}

As described in Section 2, employment tax credits are tied to aggregate expense thresholds that have to be met within the next five years for the standard plan, or seven years for the option plan. In order to determine the expected tax payments under the two alternative employment tax credit programs, we simulate sequences of annual employment expenses for each business transfer. We simulate 25 expense paths per tax credit alternative over the next five or seven years for each business transfer. We standardize the initial expenses $w_{0}$ to one since only the relative development with respect to the initial level of expenses is relevant for tax purposes. Annual employment expenses, $w_{t}$, are drawn from a normal distribution with $\mathcal{N}\left(g_{t}^{j} \times w_{t-1}, v_{t} \times w_{t-1}\right)$ for $t>0$, where $w_{t-1}$ is the simulated expense from the previous period, $g_{t}^{j}$ is the expected expense growth for an economic scenario $j$, and $v_{t} \times w_{t-1}$ is the standard deviation of the distribution. Each step relies on the last drawn expense level implying that our simulated expense realizations have a Markov property. This leads to a path dependence within each run. We further set negative draws to zero as employment expenses cannot be negative by definition, and assume $v_{t}=0.1 \forall t$. At last, we aggregate the simulated annual employment expenses over the respective time

12 The respective intervals are chosen based on the classification of the public version of the German Inheritance Tax Statistic of 2011. 
Table 2: Simulation of Economic Scenarios

\begin{tabular}{|c|c|c|c|c|c|c|c|c|}
\hline \multicolumn{9}{|c|}{ Panel A: Expected Expenditure Growth Rates } \\
\hline & & $t=1$ & $t=2$ & $t=3$ & $t=4$ & $t=5$ & $t=6$ & $t=7$ \\
\hline \multirow{2}{*}{ Base Scenario } & Standard Plan & 0.40 & -0.60 & 1.70 & 2.70 & 3.60 & - & - \\
\hline & Option Plan & 0.40 & -0.60 & 1.70 & 2.70 & 3.60 & 0.30 & 2.80 \\
\hline \multirow{2}{*}{ Recession Scenario } & Standard Plan & -6.20 & -1.60 & -2.20 & -1.70 & -5.70 & - & - \\
\hline & Option Plan & -6.20 & -1.60 & -2.20 & -1.70 & -5.70 & -2.70 & -1.60 \\
\hline \multicolumn{9}{|c|}{ Panel B: Employment Expenses under Different Scenarios } \\
\hline & & Var. & Mean & SD & $\mathrm{P} 25$ & $\mathrm{P} 50$ & P75 & $\mathrm{N}$ \\
\hline \multirow{2}{*}{ Base Scenario } & Standard Plan & $W_{S P}$ & 5.14 & 0.77 & 4.61 & 5.10 & 5.63 & 370,000 \\
\hline & Option Plan & $W_{O P}$ & 7.34 & 1.25 & 6.46 & 7.25 & 8.12 & 370,000 \\
\hline \multirow{2}{*}{ Recession Scenario } & Standard Plan & $W_{S P}$ & 4.49 & 0.69 & 4.01 & 4.45 & 4.93 & 370,000 \\
\hline & Option Plan & $W_{O P}$ & 6.10 & 1.06 & 5.36 & 6.03 & 6.77 & 370,000 \\
\hline
\end{tabular}

This table provides an overview of the simulated economic scenarios. Panel A reports the annual growth rates of the expected employment expenses in percent. Growth rates are used to simulate annual employment expenses under a base and a recession scenario. Panel B shows summary statistics for the aggregated employment expenses that result from the simulation procedure. They are reported as factors compared to the average employment expense paid in the five years preceding the transfer.

horizon, i.e., $W_{S P}=\sum_{t=1}^{5} w_{t}$ and $W_{O P}=\sum_{t=1}^{7} w_{t}{ }^{13}$

We consider two different economic scenarios - represented above by the index $j$ - for the expected expense growth in our simulation. Both scenarios rely on historical developments of aggregated salaries and wages in Germany capturing different macro-economic circumstances. This enables us to examine the impact of the macro-economic development on the effective tax burden. The first scenario, referred to as "base scenario", relies on the average annual growth rates of salaries and wages in Germany from 2003 to 2010 as reported in the German national accounts (Destatis, 2011). Panel A of Table 2 shows the annual growth rates used in the simulation. As can be seen in the table, a moderate wage increase has been observed in 6 out of 7 years. In one year a slight decrease of wages $(0.6 \%)$ occurs. The purpose of this scenario is to serve as a realistic reference point to evaluate the effects of employment tax credits under an average economic development. In contrast, the second scenario, referred to as "recession scenario", relies on the average development in the German mining industry between 2001 and 2008. ${ }^{14}$ The mining industry displayed the lowest growth of all industries considered in the national accounts. Wages shrunk in all periods with rates between $-1.6 \%$ to $-6.2 \%$.

Panel B of Table 2 reports aggregated employment expenses under both scenarios that result from the simulation. Given the 14,800 business transfers reported in the inheritance tax statistic and 25 simulated expense paths per transfer, our simulation consists of 370,000 individual runs for each tax credit plan and scenario. The results show that

\footnotetext{
13 For an illustration see Figure 2.

14 For the mining industry, growth rates of wages and salaries are only provided until 2008 by the national accounts.
} 
Figure 2: Simulated employment expense paths

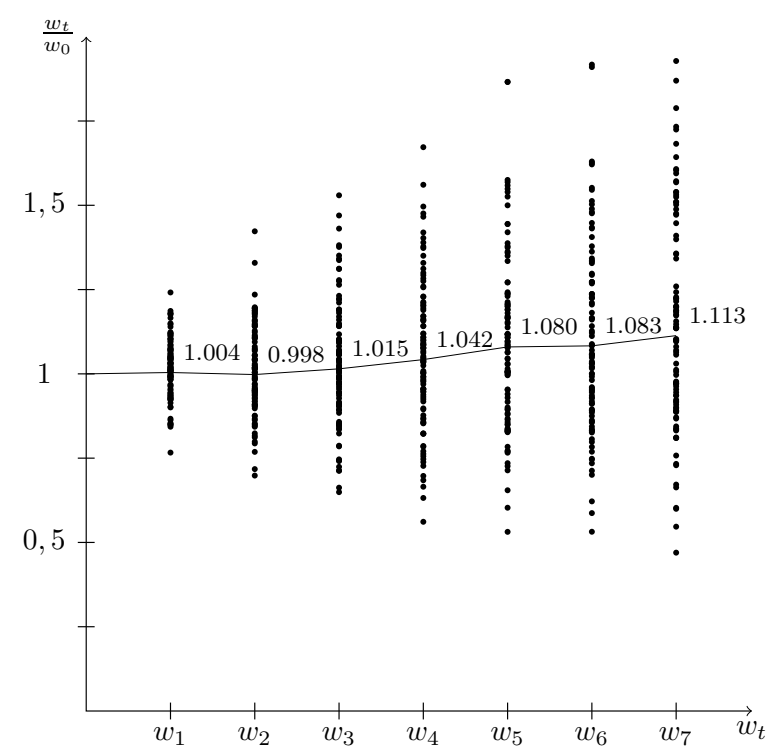

(a) Base scenario

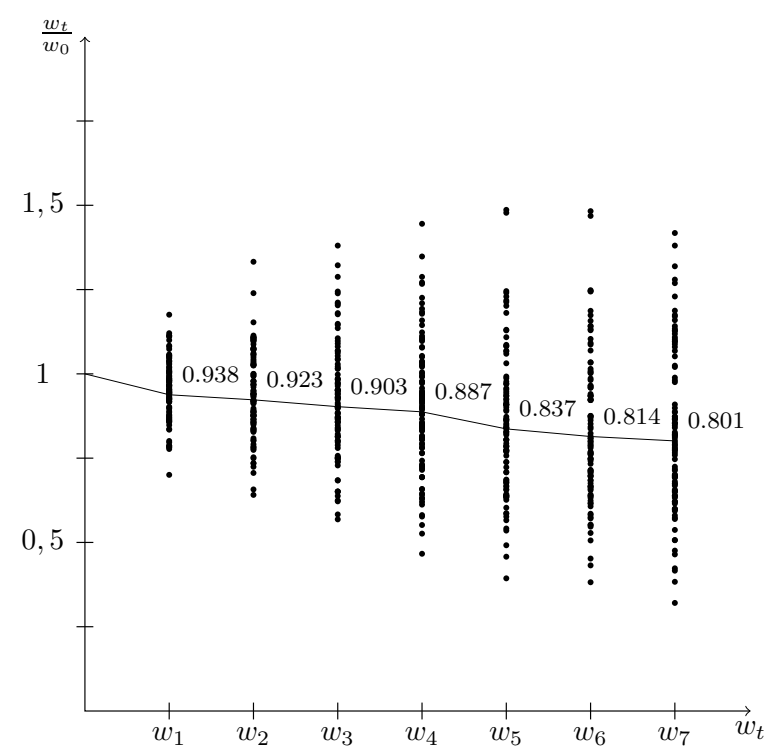

(b) Recession scenario

This figure illustrates 100 simulated expense paths under each of the two scenarios. The lines connect the means of the distribution used in the simulation as given in Table 2.

under the base scenario, mean and median values of employment expenses lie considerably above the thresholds that have to be met under the two tax credit alternatives. If the less restrictive standard plan is chosen more than $75 \%$ of the cases exceed the expense threshold. Thus, the results suggest that under an average economic development a majority of taxpayers is able to fully enjoy the tax reductions offered by the two tax credit alternatives. This picture changes under a recession scenario. While still more than $75 \%$ exceed the threshold under the standard plan, employment expenses are considerably below the levels that are required under the option plan.

Figure 2 depicts a simulation of 100 randomly chosen employment expense paths. Figure 2(a) shows the base scenario, and Figure 2(b) shows the recession scenario. We additionally report the means of the distribution used in the simulation as given in Table 2. Therefore, the mean of the 100 randomly chosen realizations differs from the reported means while a majority of realizations is still near the underlying means of the distribution. For all scenarios the spread between minimum and maximum employment expenses increases over time reflecting the problem of forecast uncertainty faced by the individual taxpayer. 


\section{Results}

We divide the analysis into three parts. First, we present results for the full sample that comprises simulated outcomes based on all business transfers included in the German Inheritance Tax Statistic of 2011 under the base scenario. We focus our discussion on how option plan, standard plan, and a non-preferential treatment affect the effective tax burden, i.e., we analyze $\tau_{i}$ for $i \in\{O P, S P, P R I V\}$. Further, we identify the percentage of cases with an effective tax rate of zero, $q_{i}$ for $i \in\{O P, S P, P R I V\}$. Moreover, we consider effects caused by a variation of the tax bracket, or by the value of the transferred property. Overall, this part of the analysis provides a representative overview of the inheritance tax burden on business transfers in an average economic environment with moderate growth rates.

Second, we focus on those cases that would be taxed in the absence of any preferential treatment. Thus, we exclude cases for which tax exemptions under private taxation are already sufficient to avoid tax payments. As a consequence, differences in the tax burden between private taxation and the two employment tax credit alternatives mainly reflect tax reductions linked to the development of employment expenses. We therefore provide a detailed analysis of the effects of employment tax credits not only under the base but also under a recession scenario.

Third, we use a multivariate approach to simultaneously consider various factors that affect the effective tax rate and the probability to pay taxes.

\subsection{Full sample analysis}

In Table 3, we provide simulation results for the full sample under the base scenario described in Section 3.2. Panel A shows that both plans that are available to business transfers provide a considerable reduction in effective tax rates compared to the treatment of private transfers. ${ }^{15}$ While private transfers would be subject to an average effective tax rate of $4.14 \%$, effective tax rates are $0.09 \%$ under the standard plan and $0.05 \%$ under the option plan. The most apparent reason for this finding is the high percentage of transfers that result in no tax payment at all. The preferential treatment of business transfers results in a zero tax rate for $97.1 \%$ of the simulation runs if the option plan is chosen. While the fraction of untaxed transfers is slightly lower under the standard plan, it is still considerably higher than it would be under the regime for transfers of private property (64.1\%). Thus, an abolishment of the preferential treatment would lead to a significantly higher effective tax burden on business transfers, and it would raise the number of taxable property transfers.

In Panel B, we report specific results for three subsamples that are split according

${ }_{15}$ Effective tax rates are computed as the percentage share of tax payments in the value of transferred property before any tax exemption, i.e., $T_{i} / X$, for $i \in\{O P, S P, P R I V\}$. 
Table 3: Simulation Results

\begin{tabular}{|c|c|c|c|c|c|c|c|c|}
\hline \multicolumn{9}{|c|}{ Panel A: Full Sample } \\
\hline & Tax Plan & Var. & Mean & SD & $\mathrm{P} 25$ & $\mathrm{P} 50$ & P75 & $\mathrm{N}$ \\
\hline \multirow{6}{*}{ Full Sample } & \multirow{2}{*}{ Standard Plan } & $\overline{\tau_{S P}}$ & 0.09 & 0.50 & 0.00 & 0.00 & 0.00 & 370,000 \\
\hline & & $q_{S P}$ & 94.7 & 0.00 & 94.7 & 94.7 & 94.7 & 370,000 \\
\hline & \multirow{2}{*}{ Option Plan } & $\tau_{O P}$ & 0.05 & 0.44 & 0.00 & 0.00 & 0.00 & 370,000 \\
\hline & & $q_{O P}$ & 97.1 & 0.00 & 97.1 & 97.1 & 97.1 & 370,000 \\
\hline & \multirow{2}{*}{ Private Taxation } & $\tau_{P R I V}$ & 4.14 & 7.51 & 0.00 & 0.00 & 5.01 & 370,000 \\
\hline & & $q_{P R I V}$ & 64.1 & 0.00 & 64.1 & 64.1 & 64.1 & 370,000 \\
\hline \multicolumn{9}{|c|}{ Panel B: By Tax Bracket } \\
\hline & Tax Plan & Var. & Mean & SD & $\mathrm{P} 25$ & $\mathrm{P} 50$ & $\mathrm{P} 75$ & $\mathrm{~N}$ \\
\hline \multirow{6}{*}{ Tax Bracket 1} & \multirow{2}{*}{ Standard Plan } & $\overline{\tau_{S P}}$ & 0.09 & 0.44 & 0.00 & 0.00 & 0.00 & 290,600 \\
\hline & & $q_{S P}$ & 94.2 & 0.00 & 94.2 & 94.2 & 94.2 & 290,600 \\
\hline & \multirow{2}{*}{ Option Plan } & $\tau_{O P}$ & 0.03 & 0.31 & 0.00 & 0.00 & 0.00 & 290,600 \\
\hline & & $q_{O P}$ & 97.9 & 0.00 & 97.9 & 97.9 & 97.9 & 290,600 \\
\hline & \multirow{2}{*}{ Private Taxation } & $\tau_{P R I V}$ & 3.15 & 6.15 & 0.00 & 0.00 & 3.02 & 290,600 \\
\hline & & $q_{P R I V}$ & 67.3 & 0.00 & 67.3 & 67.3 & 67.3 & 290,600 \\
\hline \multirow{6}{*}{ Tax Bracket 2} & \multirow{2}{*}{ Standard Plan } & $\tau_{S P}$ & 0.13 & 0.71 & 0.00 & 0.00 & 0.00 & 46,150 \\
\hline & & $q_{S P}$ & 95.5 & 0.00 & 95.5 & 95.5 & 95.5 & 46,150 \\
\hline & \multirow{2}{*}{ Option Plan } & $\tau_{O P}$ & 0.12 & 0.66 & 0.00 & 0.00 & 0.00 & 46,150 \\
\hline & & $q_{O P}$ & 93.4 & 0.00 & 93.4 & 93.4 & 93.4 & 46,150 \\
\hline & \multirow{2}{*}{ Private Taxation } & $\tau_{P R I V}$ & 7.54 & 9.46 & 0.00 & 2.26 & 13.59 & 46,150 \\
\hline & & $q_{P R I V}$ & 46.5 & 0.00 & 46.5 & 46.5 & 46.5 & 46,150 \\
\hline \multirow{6}{*}{ Tax Bracket 3} & \multirow{2}{*}{ Standard Plan } & $\tau_{S P}$ & 0.1 & 0.65 & 0.00 & 0.00 & 0.00 & 33,250 \\
\hline & & $q_{S P}$ & 97.3 & 0.00 & 97.3 & 97.3 & 97.3 & 33,250 \\
\hline & \multirow{2}{*}{ Option Plan } & $\tau_{O P}$ & 0.15 & 0.84 & 0.00 & 0.00 & 0.00 & 33,250 \\
\hline & & $q_{O P}$ & 95.0 & 0.00 & 95.0 & 95.0 & 95.0 & 33,250 \\
\hline & \multirow{2}{*}{ Private Taxation } & $\tau_{P R I V}$ & 8.05 & 11.54 & 0.00 & 0.00 & 18.55 & 33,250 \\
\hline & & $q_{P R I V}$ & 60.6 & 0.00 & 60.6 & 60.6 & 60.6 & 33,250 \\
\hline
\end{tabular}

to the legator-successor relationship. As described on page 4, business transfers between more distant relatives or to an unrelated party fall into higher tax brackets under German law. Differentiating between the three tax brackets allows for an evaluation of the effects that employment tax credits have on different groups of taxpayers. This is particularly important as differences in the taxation of diverse types of taxpayers provide incentives for succession planning. As expected our results show that in the absence of any preferential treatment, the applicable tax bracket heavily affects both the effective tax rate and the probability of paying taxes. The average effective tax rate under the tax rules applied to private property is only $3.15 \%$ for tax bracket 1 , but $7.54 \%$ for tax bracket 2 , and $8.05 \%$ for tax bracket 3. In contrast, average effective tax rates under the option and the standard plan do not exceed $0.15 \%$ even for tax bracket 3 . Thus, the preferential treatment of business transfers under current legislation reduces the effective tax burden considerably. Further, it virtually removes differences in the effective taxation of transfers 
Table 3: Simulation Results (continued)

\begin{tabular}{|c|c|c|c|c|c|c|c|c|}
\hline \multicolumn{9}{|c|}{ Panel C: By Value of Transferred Property } \\
\hline & Tax Plan & Var. & Mean & $\mathrm{SD}$ & $\mathrm{P} 25$ & $\mathrm{P} 50$ & P75 & $\mathrm{N}$ \\
\hline \multirow{6}{*}{ Small } & \multirow{2}{*}{ Standard Plan } & $\tau_{S P}$ & 0.00 & 0.00 & 0.00 & 0.00 & 0.00 & 283,850 \\
\hline & & $q_{S P}$ & 100.0 & 0.00 & 100.0 & 100.0 & 100.0 & 283,850 \\
\hline & \multirow{2}{*}{ Option Plan } & $\tau_{O P}$ & 0.02 & 0.24 & 0.00 & 0.00 & 0.00 & 283,850 \\
\hline & & $q_{O P}$ & 98.9 & 0.00 & 98.9 & 98.9 & 98.9 & 283,850 \\
\hline & \multirow{2}{*}{ Private Taxation } & $\tau_{P R I V}$ & 1.73 & 5.2 & 0.00 & 0.00 & 0.00 & 283,850 \\
\hline & & $q_{P R I V}$ & 82.3 & 0.00 & 82.3 & 82.3 & 82.3 & 283,850 \\
\hline \multirow{6}{*}{ Medium } & \multirow{2}{*}{ Standard Plan } & $\tau_{S P}$ & 0.04 & 0.28 & 0.00 & 0.00 & 0.00 & 66,450 \\
\hline & & $q_{S P}$ & 96.6 & 0.00 & 96.6 & 96.6 & 96.6 & 66,450 \\
\hline & \multirow{2}{*}{ Option Plan } & $\tau_{O P}$ & 0.06 & 0.50 & 0.00 & 0.00 & 0.00 & 66,450 \\
\hline & & $q_{O P}$ & 96.3 & 0.00 & 96.3 & 96.3 & 96.3 & 66,450 \\
\hline & \multirow{2}{*}{ Private Taxation } & $\tau_{P R I V}$ & 9.32 & 6.83 & 3.70 & 8.20 & 13.73 & 66,450 \\
\hline & & $q_{P R I V}$ & 5.50 & 0.00 & 5.50 & 5.50 & 5.50 & 66,450 \\
\hline \multirow{6}{*}{ Large } & \multirow{2}{*}{ Standard Plan } & $\tau_{S P}$ & 1.61 & 1.43 & 0.41 & 1.29 & 2.48 & 19,700 \\
\hline & & $q_{S P}$ & 11.4 & 0.00 & 11.4 & 11.4 & 11.4 & 19,700 \\
\hline & \multirow{2}{*}{ Option Plan } & $\tau_{O P}$ & 0.53 & 1.34 & 0.00 & 0.00 & 0.10 & 19,700 \\
\hline & & $q_{O P}$ & 73.0 & 0.00 & 73.0 & 73.0 & 73.0 & 19,700 \\
\hline & \multirow{2}{*}{ Private Taxation } & $\tau_{P R I V}$ & 21.41 & 6.38 & 16.82 & 17.78 & 26.40 & 19,700 \\
\hline & & $q_{P R I V}$ & 0.00 & 0.00 & 0.00 & 0.00 & 0.00 & 19,700 \\
\hline
\end{tabular}

This table provides effective tax rates and the percentage of transfers with a zero tax rate based on all business transfers provided in the German Inheritance Tax Statistic 2011. $\tau_{S P}, \tau_{O P}, \tau_{P R I V}$ denote effective tax rates under the standard plan, the option plan, and in the absence of any preferential treatment for business transfers, respectively. $q_{S P}, q_{O P}, q_{P R I V}$ denote the percentage of transfers with a zero effective tax rate under each tax treatment. All values are reported in percent. For each business transfer, 25 employment expense paths are simulated according to the base scenario described in Section 3.2. Panel A reports results of 370,000 simulation runs based on the full sample of 14,800 transfers. Panels B and C show summary statistics for subsamples by tax bracket and size of transferred property.

that belong to different tax brackets. Transfers between more distant relatives or among unrelated parties especially benefit from the current rulings.

However, the applicable tax bracket is not the only determinant of the tax burden. ${ }^{16}$ For example, the percentage of runs that result in no tax payment is lower for tax bracket 2 (46.5\%) than for tax bracket 3 (60.6\%), although the available tax exemptions for this tax bracket are higher. An apparent explanation for this finding is that the average value of transferred property is lower in tax bracket 3 than in tax bracket 2 (see Table 1). In Panel $\mathrm{C}$, we therefore present results for three subsamples that are grouped according to the value of transferred property, see page 8 . The results clearly show that the employment tax credits soften the progressivity of the tax scheme. While the average effective tax rate under private taxation would be $21.41 \%$ for transfers above 2.5 million euro, choosing the option plan allows taxpayers to only pay an average effective tax rate of $0.53 \%$ on large transfers. The choice of the option plan also leaves $73 \%$ of the large transfers untaxed,

16 We jointly consider the effect of multiple factors in Section 5.1, where we extend our analysis to a multivariate setup. 
while every large transfer would be taxed in the absence of a special treatment of business property. Thus, large transfers especially benefit from the special treatment. However, it must be noted that for large business transfers, the choice of an adequate fiscal plan plays a rather important role in reducing the effective tax burden. Under the standard plan, average and median effective tax rates are well above $1 \%$ and only $11.4 \%$ of the simulation runs result in no tax payment.

\subsection{Isolating the effects of employment tax credits}

Next, we focus on those cases that might actually benefit from a preferred tax treatment of business transfers compared to private taxation. That is, we report findings for successions that would result in a tax payment if the current inheritance tax rules for transfers of private property would be applied. This subsample consists of $35.9 \%$ of all simulation runs shown in Table $3 .{ }^{17}$ For the other transfers, generally granted tax exemptions would be sufficient to avoid any taxation. Thus, we examine those runs that are most likely to be affected by the employment tax credit. This allows us to isolate the effects of the preferential treatment of business property.

Table 4 presents the findings from a simulation of employment expenses according to the base scenario. Panel A contains all 132,725 runs of Table 3 that result in a tax payment without preferential treatment. Panels B and C show summary statistics for subsamples divided by the tax bracket and the size of transferred property, respectively. Not surprisingly, the distribution of transfers with regard to the tax brackets and the value of transferred property differs from the one in Table 3. For example, $14.84 \%$ of the transfers included in the restricted sample have a property value above 2.5 million euro, compared to only $5.32 \%$ in Table 3 .

For this subsample, tax reductions are even larger compared to the full sample analysis. The special tax treatment of business property substantially alleviates taxation if other tax exemptions are not sufficient to completely avoid taxation. The average effective tax rate under private taxation is $11.54 \%$, while employment tax credits, and additional tax exemptions for business property, help to reduce the tax burden to only $0.15 \%(0.26 \%)$ if the option plan (standard plan) is chosen. Moreover, up to $91.8 \%$ (85.2\%) of the runs that would lead to tax payments under private taxation remain untaxed under the option plan (standard plan). Panel B confirms our prior finding that an abolishment of a preferential treatment for business properties would especially hurt transfers between distant relatives or between parties without a family relationship. While those transfers would be subject to an effective tax rate of $20.44 \%$ percent under private taxation, the current treatment allows for an effective tax burden of only $0.37 \%$ under the option plan and even $0.25 \%$ under the standard plan. The results also confirm the previous finding that the current

\footnotetext{
${ }_{17}$ Slight deviations regarding the number of runs are rounding differences.
} 
Table 4: Simulation Results - Base Scenario

\begin{tabular}{|c|c|c|c|c|c|c|c|c|}
\hline \multicolumn{9}{|c|}{ Panel A: Full Sample } \\
\hline & Tax Plan & Var. & Mean & $\mathrm{SD}$ & $\mathrm{P} 25$ & P50 & P75 & $\mathrm{N}$ \\
\hline \multirow{6}{*}{ Full Sample } & \multirow{2}{*}{ Standard Plan } & $\tau_{S P}$ & 0.26 & 0.81 & 0.00 & 0.00 & 0.00 & 132,725 \\
\hline & & $q_{S P}$ & 85.2 & 0.00 & 85.2 & 85.2 & 85.2 & 132,725 \\
\hline & \multirow{2}{*}{ Option Plan } & $\tau_{O P}$ & 0.15 & 0.73 & 0.00 & 0.00 & 0.00 & 132,725 \\
\hline & & $q_{O P}$ & 91.8 & 0.00 & 91.8 & 91.8 & 91.8 & 132,725 \\
\hline & \multirow{2}{*}{ Private Taxation } & $\tau_{P R I V}$ & 11.54 & 8.48 & 3.99 & 10.86 & 16.83 & 132,725 \\
\hline & & $q_{P R I V}$ & 0.00 & 0.00 & 0.00 & 0.00 & 0.00 & 132,725 \\
\hline \multicolumn{9}{|c|}{ Panel B: By Tax Bracket } \\
\hline & Tax Plan & Var. & Mean & $\mathrm{SD}$ & $\mathrm{P} 25$ & P50 & $\mathrm{P} 75$ & $\mathrm{~N}$ \\
\hline \multirow{6}{*}{ Tax Bracket 1} & \multirow{2}{*}{ Standard Plan } & $\overline{\tau_{S P}}$ & 0.27 & 0.74 & 0.00 & 0.00 & 0.00 & 94,950 \\
\hline & & $q_{S P}$ & 82.4 & 0.00 & 82.4 & 82.4 & 82.4 & 94,950 \\
\hline & \multirow{2}{*}{ Option Plan } & $\tau_{O P}$ & 0.10 & 0.54 & 0.00 & 0.00 & 0.00 & 94,950 \\
\hline & & $q_{O P}$ & 93.5 & 0.00 & 93.5 & 93.5 & 93.5 & 94,950 \\
\hline & \multirow{2}{*}{ Private Taxation } & $\tau_{P R I V}$ & 9.64 & 7.29 & 3.19 & 8.38 & 15.08 & 94,950 \\
\hline & & $q_{P R I V}$ & 0.00 & 0.00 & 0.00 & 0.00 & 0.00 & 94,950 \\
\hline \multirow{6}{*}{ Tax Bracket 2} & \multirow{2}{*}{ Standard Plan } & $\tau_{S P}$ & 0.24 & 0.96 & 0.00 & 0.00 & 0.00 & 24,675 \\
\hline & & $q_{S P}$ & 91.6 & 0.00 & 91.6 & 91.6 & 91.6 & 24,675 \\
\hline & \multirow{2}{*}{ Option Plan } & $\tau_{O P}$ & 0.23 & 0.89 & 0.00 & 0.00 & 0.00 & 24,675 \\
\hline & & $q_{O P}$ & 87.7 & 0.00 & 87.7 & 87.7 & 87.7 & 24,675 \\
\hline & \multirow{2}{*}{ Private Taxation } & $\tau_{P R I V}$ & 14.11 & 8.66 & 7.59 & 11.57 & 18.41 & 24,675 \\
\hline & & $q_{P R I V}$ & 0.00 & 0.00 & 0.00 & 0.00 & 0.00 & 24,675 \\
\hline \multirow{6}{*}{ Tax Bracket 3} & \multirow{2}{*}{ Standard Plan } & $\tau_{S P}$ & 0.25 & 1.01 & 0.00 & 0.00 & 0.00 & 13,100 \\
\hline & & $q_{S P}$ & 93.2 & 0.00 & 93.2 & 93.2 & 93.2 & 13,100 \\
\hline & \multirow{2}{*}{ Option Plan } & $\tau_{O P}$ & 0.37 & 1.30 & 0.00 & 0.00 & 0.00 & 13,100 \\
\hline & & $q_{O P}$ & 87.3 & 0.00 & 87.3 & 87.3 & 87.3 & 13,100 \\
\hline & \multirow{2}{*}{ Private Taxation } & $\tau_{P R I V}$ & 20.44 & 9.20 & 13.52 & 23.29 & 27.52 & 13,100 \\
\hline & & $q_{P R I V}$ & 0.00 & 0.00 & 0.00 & 0.00 & 0.00 & 13,100 \\
\hline
\end{tabular}

treatment of business transfers leads to a less progressive tax scheme. For example, the difference in average effective tax rates between small and large transfers is only $0.43 \%$ under the option plan (1.61\% under the standard plan), compared to $11.65 \%$ under private taxation. $^{18}$

We have seen that employment tax credits have a large impact on the effective tax burden. As employment tax credits are tied to the development of employment expenses, we next look at the sensitivity of the preferred tax treatment toward a negative economic development. We therefore rerun our analyses from Table 4 under the recession scenario. The results are reported in Table $5{ }^{19}$ The results show that even under negative economic

18 Note that the results for large transfers reported in Panel $\mathrm{C}$ in Table 4 are identical to the ones in Table 3 as all transfers with a property value above 2.5 million euro would lead to a tax payment under private taxation.

19 Note that the effective tax rates under private taxation remain unchanged compared to Table 4 as private taxation does not provide any tax reductions based on the development of employment expenses. 
Table 4: Simulation Results - Base Scenario (continued)

\begin{tabular}{|c|c|c|c|c|c|c|c|c|}
\hline \multicolumn{9}{|c|}{ Panel C: By Value of Transferred Property } \\
\hline & Tax Plan & Var. & Mean & $\mathrm{SD}$ & $\mathrm{P} 25$ & $\mathrm{P} 50$ & P75 & $\mathrm{N}$ \\
\hline \multirow{6}{*}{ Small } & \multirow{2}{*}{ Standard Plan } & $\tau_{S P}$ & 0.00 & 0.00 & 0.00 & 0.00 & 0.00 & 50,225 \\
\hline & & $q_{S P}$ & 100.0 & 0.00 & 100.0 & 100.0 & 100.0 & 50,225 \\
\hline & \multirow{2}{*}{ Option Plan } & $\tau_{O P}$ & 0.10 & 0.57 & 0.00 & 0.00 & 0.00 & 50,225 \\
\hline & & $q_{O P}$ & 94.0 & 0.00 & 94.0 & 94.0 & 94.0 & 50,225 \\
\hline & \multirow{2}{*}{ Private Taxation } & $\tau_{P R I V}$ & 9.76 & 8.62 & 1.44 & 8.16 & 17.35 & 50,225 \\
\hline & & $q_{P R I V}$ & 0.00 & 0.00 & 0.00 & 0.00 & 0.00 & 50,225 \\
\hline \multirow{6}{*}{ Medium } & \multirow{2}{*}{ Standard Plan } & $\tau_{S P}$ & 0.04 & 0.29 & 0.00 & 0.00 & 0.00 & 62,800 \\
\hline & & $q_{S P}$ & 96.4 & 0.00 & 96.4 & 96.4 & 96.4 & 62,800 \\
\hline & \multirow{2}{*}{ Option Plan } & $\tau_{O P}$ & 0.07 & 0.51 & 0.00 & 0.00 & 0.00 & 62,800 \\
\hline & & $q_{O P}$ & 96.1 & 0.00 & 96.1 & 96.1 & 96.1 & 62,800 \\
\hline & \multirow{2}{*}{ Private Taxation } & $\tau_{P R I V}$ & 9.87 & 6.63 & 4.1 & 8.52 & 13.85 & 62,800 \\
\hline & & $q_{P R I V}$ & 0.00 & 0.00 & 0.00 & 0.00 & 0.00 & 62,800 \\
\hline \multirow{6}{*}{ Large } & \multirow{2}{*}{ Standard Plan } & $\tau_{S P}$ & 1.61 & 1.43 & 0.41 & 1.29 & 2.48 & 19,700 \\
\hline & & $q_{S P}$ & 11.4 & 0.00 & 11.4 & 11.4 & 11.4 & 19,700 \\
\hline & \multirow{2}{*}{ Option Plan } & $\tau_{O P}$ & 0.53 & 1.34 & 0.00 & 0.00 & 0.10 & 19,700 \\
\hline & & $q_{O P}$ & 73.0 & 0.00 & 73.0 & 73.0 & 73.0 & 19,700 \\
\hline & \multirow{2}{*}{ Private Taxation } & $\tau_{P R I V}$ & 21.41 & 6.38 & 16.82 & 17.78 & 26.40 & 19,700 \\
\hline & & $q_{P R I V}$ & 0.00 & 0.00 & 0.00 & 0.00 & 0.00 & 19,700 \\
\hline
\end{tabular}

This table provides effective tax rates and the percentage of transfers with a zero tax rate based on the transfers that would result in a tax payment if only the valid rules for transfers of private property would be applied. $\tau_{S P}, \tau_{O P}, \tau_{P R I V}$ denote effective tax rates under the standard plan, the option plan, and in the absence of any preferential treatment for business transfers, respectively. $q_{S P}, q_{O P}, q_{P R I V}$ denote the percentage of transfers with a zero effective tax rate under each tax treatment. All values are reported in percent. For each business transfer, 25 employment expense paths are simulated according to the base scenario described in Section 3.2. Panel A is based on all 132,725 runs that result in a tax payment under private taxation. Panels B and C show summary statistics for subsamples by tax bracket and size of transferred property.

circumstances the preferential rules for business property provide a large reduction of the effective tax burden. However, the employment tax credits, especially the option plan, are highly sensitive towards a worsening economic environment. Panel C of Table 5 shows that the effective tax rate of large transfers rises to $1.97 \%$ under a recession scenario if the option plan is chosen. This represents not only a significant increase compared to the $0.53 \%$ that result under the base scenario (see Panel C of Table 4 ). The average effective tax rate and the percentage of transfers which result in a tax payment are also higher under the option plan than under the standard plan. ${ }^{20}$ Thus, the strong tax advantage provided by the option plan under the base scenario is not preserved under a recession scenario. The sharp increase of the mean effective tax rate under the option plan can be attributed to the design of this tax credit alternative. The option plan requires tax payments only if the level of employment expenses declines during the years after the

\footnotetext{
${ }^{20}$ However, the median tax rate under the option plan is still lower than the one under the standard plan.
} 
Table 5: Simulation Results - Recession Scenario

\begin{tabular}{|c|c|c|c|c|c|c|c|c|}
\hline \multicolumn{9}{|c|}{ Panel A: Full Sample } \\
\hline & Tax Plan & Var. & Mean & $\mathrm{SD}$ & $\mathrm{P} 25$ & P50 & P75 & $\mathrm{N}$ \\
\hline \multirow{6}{*}{ Full Sample } & \multirow{2}{*}{ Standard Plan } & $\tau_{S P}$ & 0.32 & 1.00 & 0.00 & 0.00 & 0.00 & 132,725 \\
\hline & & $q_{S P}$ & 84.2 & 0.00 & 84.2 & 84.2 & 84.2 & 132,725 \\
\hline & \multirow{2}{*}{ Option Plan } & $\tau_{O P}$ & 0.59 & 1.58 & 0.00 & 0.00 & 0.00 & 132,725 \\
\hline & & $q_{O P}$ & 77.4 & 0.00 & 77.4 & 77.4 & 77.4 & 132,725 \\
\hline & \multirow{2}{*}{ Private Taxation } & $\tau_{P R I V}$ & 11.54 & 8.48 & 3.99 & 10.86 & 16.83 & 132,725 \\
\hline & & $q_{P R I V}$ & 0.00 & 0.00 & 0.00 & 0.00 & 0.00 & 132,725 \\
\hline \multicolumn{9}{|c|}{ Panel B: By Tax Bracket } \\
\hline & Tax Plan & Var. & Mean & $\mathrm{SD}$ & $\mathrm{P} 25$ & $\mathrm{P} 50$ & P75 & $\mathrm{N}$ \\
\hline \multirow{6}{*}{ Tax Bracket 1} & \multirow{2}{*}{ Standard Plan } & $\overline{\tau_{S P}}$ & 0.33 & 0.92 & 0.00 & 0.00 & 0.00 & 94,950 \\
\hline & & $q_{S P}$ & 81.2 & 0.00 & 81.2 & 81.2 & 81.2 & 94,950 \\
\hline & \multirow{2}{*}{ Option Plan } & $\tau_{O P}$ & 0.40 & 1.22 & 0.00 & 0.00 & 0.00 & 94,950 \\
\hline & & $q_{O P}$ & 81.3 & 0.00 & 81.3 & 81.3 & 81.3 & 94,950 \\
\hline & \multirow{2}{*}{ Private Taxation } & $\tau_{P R I V}$ & 9.64 & 7.29 & 3.19 & 8.38 & 15.08 & 94,950 \\
\hline & & $q_{P R I V}$ & 0.00 & 0.00 & 0.00 & 0.00 & 0.00 & 94,950 \\
\hline \multirow{6}{*}{ Tax Bracket 2} & \multirow{2}{*}{ Standard Plan } & $\tau_{S P}$ & 0.28 & 1.13 & 0.00 & 0.00 & 0.00 & 24,675 \\
\hline & & $q_{S P}$ & 91.3 & 0.00 & 91.3 & 91.3 & 91.3 & 24,675 \\
\hline & \multirow{2}{*}{ Option Plan } & $\tau_{O P}$ & 0.87 & 1.86 & 0.00 & 0.00 & 0.87 & 24,675 \\
\hline & & $q_{O P}$ & 67.1 & 0.00 & 67.1 & 67.1 & 67.1 & 24,675 \\
\hline & \multirow{2}{*}{ Private Taxation } & $\tau_{P R I V}$ & 14.11 & 8.66 & 7.59 & 11.57 & 18.41 & 24,675 \\
\hline & & $q_{P R I V}$ & 0.00 & 0.00 & 0.00 & 0.00 & 0.00 & 24,675 \\
\hline \multirow{6}{*}{ Tax Bracket 3} & \multirow{2}{*}{ Standard Plan } & $\tau_{S P}$ & 0.29 & 1.22 & 0.00 & 0.00 & 0.00 & 13,100 \\
\hline & & $q_{S P}$ & 92.7 & 0.00 & 92.7 & 92.7 & 92.7 & 13,100 \\
\hline & \multirow{2}{*}{ Option Plan } & $\tau_{O P}$ & 1.38 & 2.63 & 0.00 & 0.00 & 1.69 & 13,100 \\
\hline & & $q_{O P}$ & 67.7 & 0.00 & 67.7 & 67.7 & 67.7 & 13,100 \\
\hline & \multirow{2}{*}{ Private Taxation } & $\tau_{P R I V}$ & 20.44 & 9.2 & 13.52 & 23.29 & 27.52 & 13,100 \\
\hline & & $q_{P R I V}$ & 0.00 & 0.00 & 0.00 & 0.00 & 0.00 & 13,100 \\
\hline
\end{tabular}

succession. As the historical industry average that underlies the base scenario entails a moderate increase in employment expenses, such a decline is a rather rare event. Under a recession scenario, employment expenses decrease, causing higher tax payments. In contrast, the standard plan requires an upfront payment if the amount of tax individual exemptions is exceeded. At the same time, the employment expense threshold is less restrictive, leaving even firms with a moderate decline of employment expenses in the years following the succession without additional tax payments.

\section{Robustness tests}

\subsection{Multivariate analysis}

As a robustness check, we additionally consider the impact of our variables of interest in a multivariate framework. This is appropriate as it enables us to analyze the marginal 
Table 5: Simulation Results - Recession Scenario (continued)

\begin{tabular}{|c|c|c|c|c|c|c|c|c|}
\hline \multicolumn{9}{|c|}{ Panel C: By Value of Transferred Property } \\
\hline & Tax Plan & Var. & Mean & $\mathrm{SD}$ & $\mathrm{P} 25$ & $\mathrm{P} 50$ & P75 & $\mathrm{N}$ \\
\hline \multirow{6}{*}{ Small } & \multirow{2}{*}{ Standard Plan } & $\tau_{S P}$ & 0.00 & 0.01 & 0.00 & 0.00 & 0.00 & 50,225 \\
\hline & & $q_{S P}$ & 100.0 & 0.00 & 100.0 & 100.0 & 100.0 & 50,225 \\
\hline & \multirow{2}{*}{ Option Plan } & $\tau_{O P}$ & 0.43 & 1.29 & 0.00 & 0.00 & 0.00 & 50,225 \\
\hline & & $q_{O P}$ & 82.1 & 0.00 & 82.1 & 82.1 & 82.1 & 50,225 \\
\hline & \multirow{2}{*}{ Private Taxation } & $\tau_{P R I V}$ & 9.76 & 8.62 & 1.44 & 8.16 & 17.35 & 50,225 \\
\hline & & $q_{P R I V}$ & 0.00 & 0.00 & 0.00 & 0.00 & 0.00 & 50,225 \\
\hline \multirow{6}{*}{ Medium } & \multirow{2}{*}{ Standard Plan } & $\tau_{S P}$ & 0.07 & 0.41 & 0.00 & 0.00 & 0.00 & 62,800 \\
\hline & & $q_{S P}$ & 94.9 & 0.00 & 94.9 & 94.9 & 94.9 & 62,800 \\
\hline & \multirow{2}{*}{ Option Plan } & $\tau_{O P}$ & 0.28 & 1.12 & 0.00 & 0.00 & 0.00 & 62,800 \\
\hline & & $q_{O P}$ & 86.9 & 0.00 & 86.9 & 86.9 & 86.9 & 62,800 \\
\hline & \multirow{2}{*}{ Private Taxation } & $\tau_{P R I V}$ & 9.87 & 6.63 & 4.1 & 8.52 & 13.85 & 62,800 \\
\hline & & $q_{P R I V}$ & 0.00 & 0.00 & 0.00 & 0.00 & 0.00 & 62,800 \\
\hline \multirow{6}{*}{ Large } & \multirow{2}{*}{ Standard Plan } & $\tau_{S P}$ & 1.93 & 1.76 & 0.51 & 1.71 & 2.66 & 19,700 \\
\hline & & $q_{S P}$ & 9.9 & 0.00 & 9.9 & 9.9 & 9.9 & 19,700 \\
\hline & \multirow{2}{*}{ Option Plan } & $\tau_{O P}$ & 1.97 & 2.51 & 0.00 & 0.91 & 3.28 & 19,700 \\
\hline & & $q_{O P}$ & 34.9 & 0.00 & 34.9 & 34.9 & 34.9 & 19,700 \\
\hline & \multirow{2}{*}{ Private Taxation } & $\tau_{P R I V}$ & 21.41 & 6.38 & 16.82 & 17.78 & 26.40 & 19,700 \\
\hline & & $q_{P R I V}$ & 0.00 & 0.00 & 0.00 & 0.00 & 0.00 & 19,700 \\
\hline
\end{tabular}

This table provides effective tax rates and the percentage of transfers with a zero tax rate based on the transfers that would result in a tax payment if only the valid rules for transfers of private property would be applied. $\tau_{S P}, \tau_{O P}, \tau_{P R I V}$ denote effective tax rates under the standard plan, the option plan, and in the absence of any preferential treatment for business transfers, respectively. $q_{S P}, q_{O P}, q_{P R I V}$ denote the percentage of transfers with a zero effective tax rate under each tax treatment. All values are reported in percent. For each business transfer, 25 employment expense paths are simulated according to the recession scenario described in Section 3.2. Panel A is based on all 132,725 runs that result in a tax payment under private taxation. Panels B and C show summary statistics for subsamples by tax bracket and size of transferred property.

effects of a change to a less favorable tax bracket (compared to tax bracket 1), a larger size of the transferred property, and the choice of the option instead of the standard plan, while holding all other factors constant. We present results from logistic regressions in columns (1) and (2) of Table 6, where taxpay is an indicator variable equal to one if the expected tax payments are positive, and zero otherwise. Variables of interest are the determinants of the tax burden discussed in the previous sections. ${ }^{21}$ To compare the effects under different economic circumstances, column (1) is based on the base scenario and column (2) is based on the recession scenario. ${ }^{22} \Delta_{(1)-(2)}$ provides the difference between the coefficients shown in columns (1) and (2). The multivariate results confirm our findings from the previous sections. For example, while controlling for the value of the transferred property, the probability to pay taxes significantly increases the more distant

\footnotetext{
21 Since we conjointly include the runs for the option and the standard plan in our estimations, we suppress the subscripts used in the previous sections.

22 Estimating split regressions for each scenario allows for differences in the slopes of the coefficients.
} 
the family relationship between legator and successor. Therefore, both variables have incremental explanatory power with regard to the effective tax burden. While the option plan provides for a significantly lower probability to pay taxes than the standard plan under the base scenario, its sensitivity toward a decrease in employment expenses leads to a higher probability under a recession scenario. Comparing the regression coefficients from columns (1) and (2) shows that the effects of falling into a specific tax bracket, property size, and fiscal choice interact with the economic development. In addition to the descriptive results from the previous section, the negative values of $\Delta_{(1)-(2)}$ show that the influences of a more distant family relationship and of the property size on the probability to pay taxes are more pronounced under a recession scenario. ${ }^{23}$

Table 6: Multivariate Analysis by Economic Scenario

\begin{tabular}{|c|c|c|c|c|c|c|}
\hline \multirow{2}{*}{ Variables } & \multicolumn{2}{|c|}{ Dependent variable $=$ taxpay } & \multirow[b]{2}{*}{$\Delta_{(1)-(2)}$} & \multicolumn{2}{|c|}{ Dependent variable $=\tau$} & \multirow[b]{2}{*}{$\Delta_{(3)-(4)}$} \\
\hline & (1) & $(2)$ & & $(3)$ & $(4)$ & \\
\hline Tax Bracket 2 & $\begin{array}{c}3.110 \\
(<0.001)\end{array}$ & $\begin{array}{c}4.504 \\
(<0.001)\end{array}$ & -1.394 & $\begin{array}{c}3.277 \\
(<0.001)\end{array}$ & $\begin{array}{c}5.051 \\
(<0.001)\end{array}$ & -1.774 \\
\hline Tax Bracket 3 & $\begin{array}{c}3.109 \\
(<0.001)\end{array}$ & $\begin{array}{c}4.446 \\
(<0.001)\end{array}$ & -1.337 & $\begin{array}{c}3.746 \\
(<0.001)\end{array}$ & $\begin{array}{c}5.820 \\
(<0.001)\end{array}$ & -2.074 \\
\hline $\log (\mathrm{X})$ & $\begin{array}{c}1.682 \\
(<0.001)\end{array}$ & $\begin{array}{c}1.984 \\
(<0.001)\end{array}$ & -0.302 & $\begin{array}{c}1.600 \\
(<0.001)\end{array}$ & $\begin{array}{c}2.104 \\
(<0.001)\end{array}$ & -0.504 \\
\hline Option Plan & $\begin{array}{c}-1.204 \\
(<0.001)\end{array}$ & $\begin{array}{c}0.862 \\
(<0.001)\end{array}$ & -2.066 & $\begin{array}{c}-0.680 \\
(<0.001)\end{array}$ & $\begin{array}{c}1.366 \\
(<0.001)\end{array}$ & -2.046 \\
\hline Constant & $\begin{array}{c}-14.485 \\
(<0.001)\end{array}$ & $\begin{array}{c}-16.882 \\
(<0.001)\end{array}$ & 2.397 & $\begin{array}{c}-14.433 \\
(<0.001)\end{array}$ & $\begin{array}{c}-18.967 \\
(<0.001)\end{array}$ & 4.534 \\
\hline $\mathrm{N}$ & 740,000 & 740,000 & & 740,000 & 740,000 & \\
\hline Pseudo- $R^{2}$ & 0.562 & 0.599 & & 0.431 & 0.408 & \\
\hline
\end{tabular}

This table provides results from logistic and tobit regressions based on all business transfers provided in the German Inheritance Tax Statistic of 2011. $P$-values (based on transfer-level clustered standard errors) are reported in parentheses. The first two columns report coefficients from logit regressions using taxpay as dependent variable. taxpay equals one if a run results in a tax payment and zero otherwise. Column (1) is based on the base scenario, column (2) on the recession scenario. $\Delta_{(1)-(2)}$ compares the coefficients from columns (1) and (2); $\chi^{2}$-tests reject the null hypothesis of equal coefficients for all variables. Columns (3) and (4) report results from tobit regressions that use the effective tax rate $\tau$ as dependent variable. Column (3) is based on the base scenario, column (4) on the recession scenario. $\Delta_{(3)-(4)}$ compares the coefficients from columns (3) and (4). $\chi^{2}$-tests reject the null hypothesis of equal coefficients for all variables.

Columns (3) and (4) present the results from tobit regressions, where we use the effective tax rate $\tau$ as a dependent variable. As tax payments cannot be negative by definition, we use a censored regression model instead of standard OLS regressions to avoid estimation bias. The positive coefficients from the two regressions and the difference between the

${ }^{23}$ Note that our multivariate analyses are based on all transfers included in the German Inheritance Statistic of 2011, while section 4.2 relies on a subsample containing only transfers with positive tax payments under private taxation. 
regression coefficients $\left(\Delta_{(3)-(4)}\right)$ confirm that distant relatives have a significantly higher effective tax rate under a recession scenario. Further, the tax wedge between tax brackets 1 and the higher tax brackets increases. The impact of transferring a more valuable estate is also bigger under a recession scenario, indicating that employment tax credits lead to a more progressive tax schedule compared to the base scenario. The tax advantage from choosing the option plan reverses under a negative economic development.

As presented in Section 4 the effects of employment tax credits depend on the value of the transferred estate. Hence, we analyze the effect of the property value in a multivariate framework. We report results of separate logistic and tobit regressions in Table 7. Columns (1) to (3) show the results of logistic regressions using taxpay as dependent variable, and columns (4) to (6) report the results of tobit regressions with $\tau$ as dependent variable. We follow the classification introduced in Table 3, Panel C. That is, we estimate separate regressions based on transfers with a property values up to 500,000 euro in columns (1) and (4), between 0.5 million euro and 2.5 million euro in columns (2) and (5), and transfers exceeding 2.5 million euro in columns (3) and (6). All regressions include the standard and the option plan, as well as both the base and the recession scenario. $\Delta_{(1)-(3)}$ and $\Delta_{(4)-(6)}$ compare the coefficients from the regressions that are based on small and large properties. $\chi^{2}$-tests (not reported) confirm that all differences are significant at the $1 \%$ level.

The significant differences $\Delta_{(1)-(3)}$ and $\Delta_{(4)-(6)}$ suggest that the effects of the legatorsuccessor relationship, the development of employment expenses, and the optimal choice of an employment tax credit alternative depend on the size of the transferred property. The positive impact of falling into a higher tax bracket on both the probability to pay taxes and the effective tax rate is significantly higher for small transfers than for large transfers. Unreported results from a comparison between tobit regressions of the effective tax rate under private taxation and under the preferential treatment of business transfers confirm our prior finding that this effect is not simply due to the structure of the statutory tax rate schedule. Thus, employment tax credits alleviate the additional tax burden on higher inheritance tax brackets. The significant positive differences (1.105 and 1.859) of the coefficients for $\log (X)$ show that within the respective groups, the marginal impact of a larger estate value on the probability and the effective tax rate is also lower for large transfers than for small ones. With regard to tax planning, the results of Table 7 show that the option plan might be favorable for the transfer of large estates. However, note that the option plan is sensitive to the underlying economic scenario. For a typical economic development, the option plan should provide for a lower effective tax rate as shown in Table 6. As the regressions in Table 7 pool equal numbers of observations from the base and the regression scenario most likely overemphasize the importance of a negative economic development. 
Table 7: Multivariate Analysis by Value of Transferred Property

\begin{tabular}{|c|c|c|c|c|c|c|c|c|}
\hline \multirow[t]{2}{*}{ Variables } & \multicolumn{3}{|c|}{ Dependent variable $=$ taxpay } & \multirow[b]{2}{*}{$\Delta_{(1)-(3)}$} & \multicolumn{3}{|c|}{ Dependent variable $=\tau$} & \multirow[b]{2}{*}{$\Delta_{(4)-(6)}$} \\
\hline & $(1)$ & $(2)$ & $(3)$ & & $(4)$ & $(5)$ & $(6)$ & \\
\hline Tax Bracket 2 & $\begin{array}{c}5.455 \\
(<0.001)\end{array}$ & $\begin{array}{c}4.678 \\
(<0.001)\end{array}$ & $\begin{array}{c}0.838 \\
(<0.001)\end{array}$ & 4.617 & $\begin{array}{c}7.796 \\
(<0.001)\end{array}$ & $\begin{array}{c}5.998 \\
(<0.001)\end{array}$ & $\begin{array}{c}2.417 \\
(<0.001)\end{array}$ & 5.379 \\
\hline Tax Bracket 3 & $\begin{array}{c}5.467 \\
(<0.001)\end{array}$ & $\begin{array}{c}4.693 \\
(<0.001)\end{array}$ & $\begin{array}{c}1.019 \\
(<0.001)\end{array}$ & 4.448 & $\begin{array}{c}8.525 \\
(<0.001)\end{array}$ & $\begin{array}{c}6.81 \\
(<0.001)\end{array}$ & $\begin{array}{c}3.183 \\
(<0.001)\end{array}$ & 5.342 \\
\hline $\log (X)$ & $\begin{array}{c}1.820 \\
(<0.001)\end{array}$ & $\begin{array}{c}3.247 \\
(<0.001)\end{array}$ & $\begin{array}{c}0.715 \\
(<0.001)\end{array}$ & 1.105 & $\begin{array}{c}2.843 \\
(<0.001)\end{array}$ & $\begin{array}{c}3.692 \\
(<0.001)\end{array}$ & $\begin{array}{c}0.984 \\
(<0.001)\end{array}$ & 1.859 \\
\hline Recession & $\begin{array}{c}1.646 \\
(<0.001)\end{array}$ & $\begin{array}{c}1.451 \\
(<0.001)\end{array}$ & $\begin{array}{c}1.323 \\
(<0.001)\end{array}$ & 0.323 & $\begin{array}{c}2.475 \\
(<0.001)\end{array}$ & $\begin{array}{c}1.837 \\
(<0.001)\end{array}$ & $\begin{array}{c}1.335 \\
(<0.001)\end{array}$ & 1.140 \\
\hline Option Plan & $\begin{array}{c}8.358 \\
(<0.001)\end{array}$ & $\begin{array}{c}1.118 \\
(<0.001)\end{array}$ & $\begin{array}{c}-2.632 \\
(<0.001)\end{array}$ & 10.990 & $\begin{array}{c}11.553 \\
(<0.001)\end{array}$ & $\begin{array}{c}1.743 \\
(<0.001)\end{array}$ & $\begin{array}{c}-1.284 \\
(<0.001)\end{array}$ & 12.837 \\
\hline Constant & $\begin{array}{l}-25.040 \\
(<0.001)\end{array}$ & $\begin{array}{c}-28.206 \\
(<0.001)\end{array}$ & $\begin{array}{c}-4.656 \\
(<0.001)\end{array}$ & -20.384 & $\begin{array}{c}-37.600 \\
(<0.001)\end{array}$ & $\begin{array}{c}-33.312 \\
(<0.001)\end{array}$ & $\begin{array}{c}-8.054 \\
(<0.001)\end{array}$ & -29.546 \\
\hline $\mathrm{N}$ & $1,135,400$ & 265,800 & 78,800 & & $1,135,400$ & 265,800 & 78,800 & \\
\hline Pseudo- $R^{2}$ & 0.586 & 0.420 & 0.284 & & 0.439 & 0.323 & 0.121 & \\
\hline
\end{tabular}

This table provides results from logistic and tobit regressions based on all business transfers provided in the German Inheritance Tax Statistic of 2011. $P$-values (based on transfer-level clustered standard errors) are reported in parentheses. The first three columns report coefficients from logit regressions using taxpay as dependent variable. taxpay equals one if a run results in a tax payment and zero otherwise. Column (1) only considers transfers up to 500,000 euro, column (2) transfers between 500,000 and 2.5 million euro, and column (3) transfers above 2.5 million euro. $\Delta_{(1)-(3)}$ compares the coefficients from columns (1) and (3); $\chi^{2}$-tests reject the null hypothesis of equal coefficients for all variables. Columns (4) to (6) report results from tobit regressions that use the effective tax rate $\tau$ as dependent variable. Column (4) only considers transfers up to 500,000 euro, column (5) transfers between 500,000 and 2.5 million euro, and column (6) transfers above 2.5 million euro. $\Delta_{(4)-(6)}$ compares the coefficients from columns (4) and (6); $\chi^{2}$-tests reject the null hypothesis of equal coefficients for all variables.

\subsection{Endogeneity of employment expenses}

The two tax credit alternatives have been introduced to avoid additional liquidity strains that might have an impact on employment. Further, they could even create incentives to increase employment expenses beyond the level that is optimal under a non-tax environment. This entails a potential endogeneity issue, since we assume that employment expenses are determined for non-tax reasons.

To address this concern, we first calculate the marginal tax reduction that could be achieved by marginally increasing aggregated employment expenses under the standard plan and the option plan, $W_{S P}$ and $W_{O P}$. Therefore, we compute the first-order derivatives of (3) and (4) with respect to $W_{S P}$ and $W_{O P}$, respectively. We then take the argument that maximizes the potential savings from an increase in employment expenses. ${ }^{24}$ We then compare the potential marginal tax savings with the additional employment expenses. Thereby, we consider a $20 \%$ employer's share in social security contributions. These contributions are not included in the calculation of $W$ for tax purposes. However, the successor would include these contributions as cost in his employment decision. Therefore,

$\overline{24}$ According to the our approach in the previous sections we assume $r$ to equal zero. 
for the standard plan, a marginal increase in employment expenses would be economically useful, if

$$
\frac{w_{0}}{X} \leq \frac{0.85 \cdot t_{S P}}{4.8}
$$

If the option plan is chosen, marginal tax reductions overcompensate additional employment expenses, if

$$
\frac{w_{0}}{X} \leq \frac{t_{O P}}{8.4}
$$

As firm-specific data on the actual employment expenses paid by our sample firms in the years preceding the transfer, $w_{0}$, is not available, we evaluate the extent of the endogeneity problem by estimating the fraction of $w_{0}$ to $X$ under both scenarios by using the tax rates $t_{S P}$ and $t_{O P}$. Consequently, we compute the maximum ratio of $w_{0}$ to $X$ so that a given percentage of firms would have an incentive to increase employment only for tax reasons if their simulated ratios are below the respective threshold.

Table 8: Incentives to Increase Employment Expenses

\begin{tabular}{llcccccccc}
\hline \hline & & $p=20 \%$ & $p=10 \%$ & $p=5 \%$ & $p=4 \%$ & $p=3 \%$ & $p=2 \%$ & $p=1 \%$ \\
\hline \multirow{2}{*}{ Base Scenario } & Standard Plan & 0 & 0.021 & 0.034 & 0.034 & 0.034 & 0.041 & 0.053 \\
& Option Plan & 0 & 0 & 0.018 & 0.018 & 0.023 & 0.024 & 0.036 \\
\multirow{2}{*}{ Recession Scenario } & Standard Plan & 0 & 0.027 & 0.034 & 0.034 & 0.035 & 0.041 & 0.053 \\
& Option Plan & 0.013 & 0.023 & 0.024 & 0.030 & 0.036 & 0.036 & 0.036 \\
\hline \hline
\end{tabular}

This table provides thresholds for the fractions of $w_{0}$ to $X$ so that simulation runs with a ratio below the threshold have incentives to increase the level of employment expenses for tax reasons. Thereby, $p$ is the percentage of simulation runs that have incentives to increase employment for tax reasons. Thresholds are computed separately for both the standard and the option plan under the base scenario and the recession scenario.

The results reported in Table 8 show that only highly capital intensive businesses might have an incentive to increase employment over the level that would be optimal under a non-tax environment. For example, the threshold of $5.3 \%$ at the $1 \%$ level means that $1 \%$ of the runs would provide incentives to voluntarily increase employment if the ratio of average employment expenses to the value of transferred property for the respective firms is below this critical value. ${ }^{25}$ Under the option plan, this threshold is even lower $(3.6 \%$ of the property value). While we can still not rule out all endogeneity concerns completely, it is very unlikely that firms fall below this threshold. An exception (if any) might be a few (if any) large and capital-intensive firms that are subject to a high tax rate. From a public policy perspective, the analysis also indicates that the current preferential tax treatment does not provide material incentives to increase employment.

$\overline{25}$ For example, if we assume the average equity ratio for German SMEs in 2012 of 27.4\% (Kreditanstalt für Wiederaufbau (2013)), a business with annual employment expenses of 800,000 euro would only meet the threshold if its property value exceeded 55.089 million euro. 


\section{Conclusion}

This study provides a comprehensive overview on the effects of employment tax credits for business transfers on the effective tax burden. Based on micro-level data from the German Inheritance Tax Statistic of 2011, we calculate effective tax rates resulting under two different economic scenarios for both tax credit alternatives that are provided by German inheritance tax law. The simulation considers in detail the design of the two alternatives as well as specific tax exemptions granted for business transfers. We evaluate the implications of employment tax credits by comparing the effective tax rates for business transfers with the tax burden that would result under a non-preferential treatment.

The first part of the analysis provides evidence on the expected tax effects based on the characteristics of all inheritance tax cases included in the German Inheritance Tax Statistic. The results show that both the probability to pay taxes and the effective tax rate are strongly affected by the preferential treatment of business property. For example, the average effective tax rate is reduced from $4.14 \%$ for private transfers to $0.05 \%$ if the most favorable employment tax credit alternative is used. Moreover, tax reductions are not granted uniformly to all tax brackets. The tax wedge between transfers among close relatives and among distant relatives, i.e, low and high inheritance tax brackets, is significantly reduced compared to the treatment under private taxation. Last, employment tax credits smoothen the progressivity of the inheritance taxation and allow $73 \%$ of the large transfers to remain untaxed.

Next, we focus on a subsample of transfers that would be taxed under private taxation. These transfers are of particular interest as they are the ones that can potentially benefit from employment tax credits. As expected, our prior findings that employment tax credits strongly reduce the effective tax burden and smooth the differences between high and low tax brackets as well as large and small transfers are confirmed. In addition, we show that the tax reduction is significantly smaller under a negative economic scenario. We additionally run multivariate tests where we consider the impact of the different determinants of the effective tax burden simultaneously. The robustness checks confirm our previous findings. With regard to fiscal planning, we find that the option plan, which allows for zero tax payments if expense thresholds are met, is advantageous under most circumstances. Last, we address the possibility that employment expenses could be endogenously determined. Based on our simulation results we show that the current inheritance tax legislation provides little if any incentives to increase employment beyond the level that would be chosen for non-tax reasons.

The proper design and the usefulness of employment tax credits are subject to current political discussions in both the US and in Europe. Moreover, the German Federal Constitutional Court has to decide on whether the provisions analyzed in this study are consistent with the German constitution. Therefore, evidence on the fiscal effects of em- 
ployment tax credits is useful both for political and judicial purposes. The results of this study can help to substantiate discussions on the costs and benefits of employment tax credits. Specifically, they show that a change of the current legislation is likely to affect succession planning as transfers to unrelated successors would probably be subject to a significantly higher effective tax rate. Moreover, they highlight the effects of employment tax credits on tax progressivity. Summarizing, transfers of large business properties among distant relatives or unrelated parties benefit from employment tax credits under non-recession conditions. Further, our results suggest pro-cyclical effects of the analyzed employment tax credits. 


\section{References}

Bartik, T. and Bishop, J. (2009). The Job Creation Tax Credit: Dismal projections for employment call for a quick, efficient, and effective response. Economic Policy Institute Briefing Paper No. 248. Washington, DC: Economic Policy Institute.

Batchelder, L. (2009). Estate tax reform: issues and options. Tax Notes NYU Law and Economics Research Papers No. 09-02.

BFH - Bundesfinanzhof (2012). Entscheidung vom 27.9.2012 (II R 9/11) [Decision of the German Federal Fiscal Court, 9/27/2012].

BVerfG - Bundesverfassungsgericht (2012). Normenkontrollverfahren (1 BvL 21/12) [Pending proceeding of the German Federal Constitutional Court].

Destatis - Statistisches Bundesamt (2011). VGR der Länder - Arbeitnehmerentgelt, Bruttolöhne und -gehälter in den Ländern [German National Statistical Office - National accounts - gross wages and salaries]. Wiesbaden, Germany.

Deutscher Bundestag (2008). Entwurf eines Gesetzes zur Reform des Erbschaftsteuerund Bewertungsrechts (Erbschaftsteuerreformgesetz - ErbStRG) [Draft on a reform of the inheritance tax and valuation law]. Bundestags-Drucksache 16/r918, 28.1.2008.

Eurostat - European Commission (2012). Taxation trends in the European Union. Data for the EU member states, Iceland and Norway.

Heaton, P. (2012). The effects of hiring tax credits on employment of disabled veterans. RAND Occasional Paper Series, OP-366-OSD.

Houben, H. and Maiterth, R. (2011). Endangering of usinesses by the German inheritance tax? An empirical analysis. Business Research, 4(1):32-46.

Kopczuk, W. (2013). Taxation and intergenerational transfer of wealth. In Auerbach, A., Chetty, R., Feldstein, M., and Saez, E., editors, Handbook of Public Economics. Elsevier.

Kreditanstalt für Wiederaufbau (2013). KfW-Mittelstandspanel 2013 [KfW Panel on small and medium entities 2013]. Frankfurt, Germany.

Miller, D., Steier, L., and Le Breton-Miller, I. (2003). Lost in time: intergenerational succession, change, and failure in family business. Journal of Business Venturing, $18(4): 513-531$.

Ministry of Finance Japan (2010). FY 2011 Tax Reform (Main Points). http://www . mof .go.jp/english/tax_policy/tax_reform/. 
Müller, J. and Sureth, C. (2011). Marktnahe Bewertung von Unternehmen nach der Erbschaftsteuerreform? [Approximate market valuation of businesses after the inheritence tax reform]. Zeitschrift für betriebswirtschaftliche Forschung Sonderheft, 63(11):45-83.

Næss-Schmidt, H., Pedersen, T., Harhoff, F., Winiarczyk, M., and Jervelund, C. (2011). Study on inheritance taxes in EU member states and possible mechanisms to resolve problems of double inheritance taxation in the EU. Copenhagen Economics.

Neumark, D. (2011). Policies to encourage job creation: hiring credits vs. worker subsidies. National Bureau of Economic Research Working Paper Series, NBER Working Paper No. 16866.

Perloff, J. and Walter, M. (1979). The New Jobs Tax Credit: An evaluation of the 1977-78 wage subsidy program. American Economic Review, 69(2):173-179.

Pickety, T. and Saez, E. (2007). How progressive is the U.S. federal tax system? A historical and international perspective. Journal of Economic Perspectives, 21(1):3-24.

Profeta, P., Scabrosetti, S., and Winer, S. (2014). Wealth transfer taxation: an empirical investigation. International Tax and Public Finance, 21(4):720-767.

Simons, D., Voeller, D., and Corsten, M. (2012). Erbschaftsteuerliche Verschonungsregeln für das Betriebsvermögen? Ein theoretischer Ansatz zur Steuerplanung [Inheritance tax credits for business property - a theoretical approach to fiscal planning]. Zeitschrift für betriebswirtschaftliche Forschung, 64(2):2-36.

The White House (ed.) (2012). The president's framework for business tax reform. Joint report by the White House and the Department of the Treasury. 